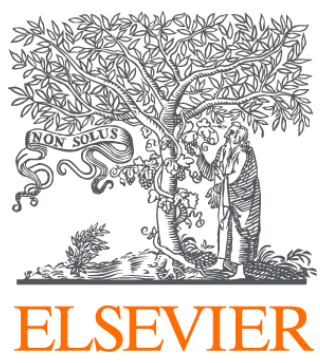

Since January 2020 Elsevier has created a COVID-19 resource centre with free information in English and Mandarin on the novel coronavirus COVID-

19. The COVID-19 resource centre is hosted on Elsevier Connect, the company's public news and information website.

Elsevier hereby grants permission to make all its COVID-19-related research that is available on the COVID-19 resource centre - including this research content - immediately available in PubMed Central and other publicly funded repositories, such as the WHO COVID database with rights for unrestricted research re-use and analyses in any form or by any means with acknowledgement of the original source. These permissions are granted for free by Elsevier for as long as the COVID-19 resource centre remains active. 
Chapter 12. Antiviral Agents

James L. Kelley

Wellcome Research Laboratories, Burroughs Wellcome Co. Research Triangle Park, NC 27709

The previous review of antiviral agents in Annual Reports in Medicinal Chemistry emphasized compounds with activity against DNA viruses. ' The focus of this year's chapter is on agents with activity primarily against RNA viruses. A brief update of this year's advances in anti-DNA virus agents is provided. Antiviral agents with activity against RNA viruses were previously reviewed in the 1981 volume.? Neither interferons nor interferon inducers are included in this review as they were covered in the 1981 and 1982 volumes, respectively. Several reviews have been published that give an overview of the most promising clinical and experimental antiviral agents $3-5$ or provide background on viral diseases. ${ }^{6-8}$ More comprehensive reviews dealing with specific drugs are cited in the sections where these compounds are discussed.

\section{VIRAL RESPIRATORY DISEASE}

RNA viruses are the major causative factors of the various forms of acute respiratory disease. 8 The communicable diseases of the respiratory tract are probably the most common cause of symptomatic human infections. Among both children and adults, acute respiratory tract illness results in significant morbidity, lost time from work, physician visits, and death. It has been calculated that throughout the world over two million deaths occur annually from acute respiratory disease. 9 The viruses that are causative agents for human respiratory disease comprise the five taxonomically distinct families Orthomyxoviridae, Paramyxoviridae, Picornaviridae, Coronaviridae and Adenoviridae. 9 The influenza viruses, which are comprised of types $A, B$ and $C$, belong to the family Orthomyxoviridae. Types $A$ and $B$ have been associated with significant increases in mortality during epidemics. The disease may be asymptomatic or cause symptoms ranging from the common cold to fatal pneumonia. Immunization against influenza has been recommended for high-risk groups, and antiviral chemotherapy (amantadine) is available for the treatment and prophylaxis of all influenza $A$ infections. The family Paramyxoviridae includes respiratory syncytial virus (RSV) and parainfluenza virus which are a major cause of lower respiratory tract infections. RSV is a factor in severe bronchiolitis and pneumonia in infants and young children. Efforts to develop a vaccine for RSV have been ineffectual, but recent clinical trials with ribavirin as a small particle aerosol have been promising. The parainfluenza viruses, of which there are four human serotypes, are second only to RSV as a cause of lower respiratory tract illness. There is both a great need for and interest in developing a chemotherapeutic agent for treatment of these two viral, respiratory tract pathogens. The family Picornaviridae contains the genus Rhinovirus, which is composed of over a hundred distinct serotypes. The rhinoviruses are recognized as the most important causative agents of the 
common cold. The development of a vaccine has been precluded due to the many rhinovirus serotypes. Although a number of different chemical agents have been tested in man, none has shown much clinical efficacy. Coronaviruse (family Coronaviridae) also has an appreciable role in upper respiratory tract illness although technical difficulties appear to have hindered studies on vaccines and antiviral agents. The adenoviruses (family Adenoviridae) are a ubiquitous group of doublestranded DNA viruses which are responsible for a wide variety of respiratory illnesses. These infections are most common among children, although acute respiratory disease and pneumonia are also common among military recruits. Two comprehensive reviews of viral respiratory diseases and measures for their control and treatment have been recently published. 8,9

\section{AGENTS ACTIVE PRIMARILY AGAINST RNA VIRUSES}

Amantadine (1-adamantanamine) and rimantadine (a-methy1-1-adamantanemethylamine) - Amantadine (1) and rimantadine () are specifically active<smiles>[R]C12CC3CC(CC(C3)C1)C2</smiles>

1, $\mathrm{R}=\mathrm{NH}_{2}$ against influenza A virus infections. In 1966 amantadine was licensed for general use against

2. $\mathrm{R}=\mathrm{CHCH}_{3} \mathrm{NH}_{2}$ Asian (H2N2) influenza in the United States and since 1976 has had FDA approval for the prophylaxis and therapy of all influenza $A$ infections. 10,11 Rimantadine is a closely related analog that has been widely used in the U.S.S.R. A review of the results of experimental and clinical studies performed in the U.S.S.R. With rimantadine has been published. 12 Several placebo-controlled, double-blind clinical trials of amantadine and rimantadine in the treatment of influenza $A$ infections have been recently completed.13-15 In a large-scale trial, both drugs were highly effective with no significant differences between the rates of illness or infection in the two drug-treated groups. 13 The amantadine recipients reported a higher incidence of side effects largely attributed to central nervous system (CNS) symptoms.13,14 This difference in side effects may be a pharmacokinetic phenomenon which results in higher plasma concentrations of amantadine. 16 A controlled study of healthy, adult volunteers found 1 and $\underline{2}$ to have minor side effects comparable to those of a common antihistamine. 17 However, an open study involving hospital employees receiving amantadine showed a high incidence of CNS symptoms. ${ }^{18}$ Guidelines for the use of amantadine in patients with impaired renal function have been formulated from the results of pharmacokinetic studies on amantadine in patients with normal and impaired renal function. 19,20 Since approximately $90 \%$ of an oral dose of amantadine is excreted unchanged in the urine, patients with renal insufficiency can accumulate the drug, resulting in toxic manifestations. The mechanism by which 1 and $\underline{2}$ inhibit influenza $A$ virus replication had previously been narrowed to a virus-specific event after virus penetration but prior to primary transcription. A recent study with virus labeled with radioactive precursors seems to show that uncoating is a multistep process. 21 Rimantadine prevents the second step of uncoating, the release of matrix (M) protein from ribonucleoproteins (RNP). 22 This blocks the penetration of RNP into the nucleus and prevents the nuclear phase of virus reproduction. Amantadine produces the same effect on uncoating as rimantadine. 21 These adamantyl amines may also have utility in the treatment of other types of viral infections. Rimantadine has been shown to be an effective inhibitor of dengue virus replication in vitro. 23 The amelioration of post-herpetic neuralgia due to recurrent herpes simplex sciatica 24 and from acute herpes zoster 25 has been reported with early administration of amantadine. 
Ribavirin (1-B-D-ribofuranosyl-1,2,4-triazole-3-carboxamide) - This nucleoside has activity against a broad range of DNA and RNA viruses in tissue culture and in animal model systems. 2 An

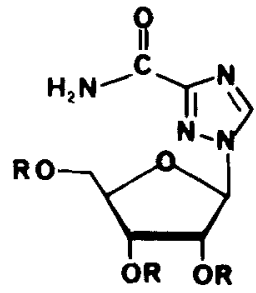

$\underline{3}, \mathbf{R}=\mathbf{H}$

$4, R=\mathrm{COCH}_{3}$ analysis of the status of ribavirin (3) as an antiviral agent has been published. $26^{2}$ Its mechanism is still unresolved but may involve guanosine nucleotides and inhibition of inosine monophosphate dehydrogenase. 26 In a clinical trial against influenza $A$, oral ribavirin failed to alter clinical signs and symptoms of the disease. ${ }^{2}$ However, it has recently been reported to have a therapeutic effect against both influenza $A$ and influenza $B$ virus infections when administered to patients by inhalation of small-particle aerosol through a face mask.27,28 This method of treatment may

find utility in those patients at high risk such as the elderly and the chronically ill. Ribavirin has also been shown to inhibit respiratory syncytial virus (RSV) infection in an animal model when administered i.p. or by aerosol treatment. 29 This in vivo activity has now been substantiated in two controlled, double-blind clinical trials. 30,31 Administration of a continuous aerosol of ribavirin to infants hospitalized with lower respiratory tract disease from RSV resulted in significant clinical improvement. 31 In a study of the effects of several antiviral agents against Colorado tick fever virus (CTFV), ribavirin inhibited CTFV in vitro. 32 Ribavirin did not protect mice inoculated intracerebrally with CTFV. However, the $2^{\prime}, 3^{\prime}, 5^{\prime}$-triacetate derivative 4 significantly increased the number of survivors when administered i.p., which suggests that this lipophilic prodrug of ribavirin is able to cross the blood-brain barrier. 32 Intraperitoneal administration of 4 was also found to protect mice inoculated intracerebrally with dengue virus, under conditions where ribavirin had no significant protective effect. 33 In another study, ribavirin reduced the growth of four types of dengue virus in vitro, but it had no effect on virus replication in human peripheral blood leukocytes (PBL) which have been implicated in the pathogenesis of dengue virus in vivo. 34 However, a combination of ribavirin with 6-mercapto-9-(tetrahydro-2furyl)purine, an inhibitor of hypoxanthine-guanine phosphoribosyl transferase, resulted in a marked suppression of dengue virus replication in human PBL. 34

Selenazole (2-B-D-ribofuranosylselenazole-4-carboxamide) - The novel selenazole carboxamide nucleoside 5 was recently synthesized 35 , and it has been reported to have in vitro antiviral activity superior to that of ribavirin. 36 selenazole $(\underline{5})$ has broad-spectrum antiviral activity<smiles></smiles>

$\underline{5}$ against both RNA and DNA viruses, but it was most active against representative RNA viruses. 36 The virus families Paramyxoviridae, Reoviridae, Togaviridae, Bunyaviridae and Arenaviridae were particularly sensitive with $E_{50}$ values typically ranging from 1 to $8 \mu \mathrm{g} / \mathrm{ml}$, although yellow fever virus was especially sensitive with an $E D_{50}=$ $0.005 \mu \mathrm{g} / \mathrm{ml}$. Although selenazole was relatively nontoxic for Vero and HeLa cells, 36 it was found to be cytotoxic towards P388 and L1210 cells in culture and exhibited marked activity against Lewis lung carcinoma in mice. 35 
Carbocyclic 3-deazaadenosine ( $\mathrm{C}-\mathrm{c}^{3} \mathrm{Ado}$ ) - The carbocyclic nucleoside 6

has been reported to inhibit the in vitro replication of
DNA and RNA viruses 1,37 . C-c 3 Ado was active against
vaccinia, reo, measles, parainfluenza and vesicular
stomatitis viruses (VSV) at concentrations from
0.2 to $1 \mu \mathrm{g} / \mathrm{ml}$ but exhibited no toxicity for the host
cells at $400 \mu \mathrm{g} / \mathrm{ml}$. In vivo, 6 protected newborn mice
against a lethal infection of VSV when administered i.p.
Its spectrum of antiviral activity was suggested to be
compatible with an impairment of viral mRNA transcription
and/or processing. 37

Enviroxime (LY 122772) - Enviroxime ( 7 ) is a potent inhibitor of rhinovirus replication in cell culture with a uniform level of activity<smiles>[X]C(c1ccccc1)c1ccc2nc(N)n(S(=O)(=O)OCC)c2c1</smiles>

7, $X=$ NOH - anti

$8, \mathrm{X}=\mathrm{CHCH}_{3}-$ trans against over sixty rhinovirus serotypes. 2 In clinical trials in England, intranasal and oral enviroxime had some beneficial effect on rhinovirus infections al though the oral form was poorly tolerated. 38,39 In two U.S.A. based clinical trials, prophylactic administration of intranasal enviroxime failed to prevent infection or to reduce the frequency of colds after experimental rhinovirus challenge. 40,41 Enviroxime, as its syn-anti mixture, and the propenyl analog 8 ( $L Y$ 127123) have been reported to be highly active against thirteen enteroviruses in vitro. 42 When injected s.c. into infant mice, both compounds significantly reduced the mortality caused by Echo and coxsackie viruses. 42 A number of analogs of the olefin $\underline{8}$ in which $\mathrm{X}$ was equal to groups as diverse as $\mathrm{CHCH}_{2} \mathrm{CH}_{3}, \mathrm{CHC} \equiv \mathrm{N}$, $\mathrm{CHCONH}_{2}, \mathrm{CHCOOCH}_{3}$ and $\mathrm{CHCl}$ were reported to have potent in vitro activity against poliovirus with $I_{50}$ 's ranging from 0.01 to $0.04 \mu \mathrm{g} / \mathrm{ml} .43$ Activity is highly specific for the E-isomer, a trend that parallels earlier findings in the enviroxime series. 44

The recent literature on 2-( $\alpha$-hydroxybenzy l)benzimidazole (HBB) and several analogs has been reviewed. 45 The in vitro antiviral activity of 9 against thirteen enteroviruses in comparison with enviroxime and in combination with guanidine has been published. 42 The mutual synergistic activity of the combination of 9 and guanidine was confirmed against Echo and coxsackie viruses in infant mice. 42,46<smiles>OC(c1ccccc1)c1nc2ccccc2[nH]1</smiles><smiles>CCCNC(=N)c1ccc2[nH]c(CC)nc2c1</smiles>

Mono- and diamidinobenzimidazoles such as bis(5-amidino-2benzimidazolyl)methane (BABIM) (10) possess significant suppressive effects on the cytopathology and yield of respiratory syncytial virus (RSV). 47 The mechanism of action of BABIM may be related to its inhibition of certain trypsin-like proteases, 47 but a study of twenty-four amidine derivatives showed no correlation between RSV-induced cell fusion and inhibition of four protease enzymes. 48 
4',6-Dichloroflavan (BW683C) - BW683C (11) is a potent inhibitor of the in vitro replication of several serotypes of rhinovirus. 49 The ${ }^{4} C_{50}$ value for 19 against serotype $1 \mathrm{~B}$ is $7 \mathrm{nM}$.<smiles>Clc1ccc(C2CCc3cc(Cl)ccc3O2)cc1</smiles>

11

However, the sensitivity of the nineteen serotypes against which 11 was tested was highly variable. BW683C was found to be most active when added to the cell culture simultaneously with the virus. 50 The compound does not interfere with virus adsorption to cells nor with uncoating of the viral RNA. It appears to bind directly to rhinovirus $1 \mathrm{~B}$ and may prevent virus replication immediately following uncoating of the viral RNA. 50 The compound is relatively nontoxic as no untoward effects were evident with HeLa cells at concentrations up to $3.6 \mu \mathrm{M}$. In rats, no ill effects were observed after oral administration of up to $1000 \mathrm{mg} / \mathrm{kg}$ or $i . p$. administration of up to $700 \mathrm{mg} / \mathrm{kg} .49$ In a double-blind, placebocontrolled volunteer trial, oral BW683C failed to produce a consistent reduction in any of the quantitative indices of rhinovirus infection. 51 Administration of this antiviral agent by inhalation may prove to be more efficacious. 52

4',5-Dihydroxy-3,3',7-trimethoxyflavone (Ro 09-0179) - Ro 09-0179 (12), which was originally isolated from a<smiles>[R20]c1ccc(-c2oc3cc(OC)cc([R])c3c(=O)c2OC)cc1OC</smiles>

$12, R=H$

$\underline{13}, \mathrm{R}=\mathrm{COCH}_{3}$ Chinese medicinal herb, is a selective inhibitor of the replication of human picornaviruses. 53 Its $\mathrm{IC}_{50}$ against twenty serotypes of rhinovirus was $0.1 \mu \mathrm{g} / \mathrm{ml}$ in HeLa or WI -38 cells, and its $50 \%$ cytotoxic dose was about $15 \mu \mathrm{g} / \mathrm{ml}$. The compound does not directly inactivate the virus, but it was most effective when present in the early stages of virus replication. Although 12 was not active in vivo, its diacetyl derivative 13 (Ro 09-0298) was orally effective in protecting mice from lethal infections with coxsackievirus B1.53 The closely related natural product, quercetin, has antiviral activity both in vitro and in vivo. 54 Additional studies with quercetin against Mengo $\bar{M}$ virus infected mice have confirmed previous reports of its oral efficacy. 54,55

4'-Ethoxy-2'-hydroxy-4,6'-dimethoxychalcone (Ro 09-0410) - An agent active exclusively against rhinoviruses has emerged from a synthes is program on analogs of the flavone Ro 09-0179 (12). Ro 09-0410 (14), a<smiles>COc1ccc(/C=C/C(=O)c2c(O)cc(OC)cc2OC)cc1</smiles>

$\underline{14}$ chalcone, has activity against 46 of the 53 serotypes tested with $\mathrm{IC}_{50}$ s ranging from $3 \mu \mathrm{gg} / \mathrm{ml}$ to less than $0.003 \mu \mathrm{g} / \mathrm{ml} .56$ In contrast, 14 was inactive against nine other DNA and RNA

viruses at concentrations up to $3 \mu \mathrm{g} / \mathrm{ml}$. Toxicological studies in rodents produced no adverse effects at a daily oral dose of $1000 \mathrm{mg} / \mathrm{kg}$ for two weeks. A phosphate ester (Ro 09-0415) of 14 has been evaluated in humans at the MRC Common Cold Unit in Salsbury, England. 57

2-(3,4-Dichlorophenoxy)-5-nitrobenzonitrile (MDL-860) - MDL-860 (15) is a selective inhibitor of picornavirus replication in vitro. 58 at a concentration of $1.0 \mathrm{\mu g} / \mathrm{ml}, 15$ caused a reduction in virus yield of at 
<smiles>N#Cc1cc([N+](=O)[O-])ccc1Oc1ccc(Cl)c(Cl)c1</smiles>

15

least ten fold in eight of ten enteroviruses and seventy-two of ninty rhinovirus serotypes, but it had no effect on six other types of viruses. 58 MDL-860 does not directly inactivate the virus nor does it inhibit virus uncoating. 59 Although 15 had no adverse effects on RNA or protein synthesis of uninfected HeLa cells, it was found to inhibit viral RNA synthesis when added shortly after virus absorption.

Sodium 5-aminosulfonyl-2,4-dichlorobenzoate (M12325) - A broad spectrum<smiles>NS(=O)(=O)c1cc(S(N)(=O)=O)c(Cl)cc1Cl</smiles>

16 of activity against RNA viruses in vitro and in vivo has been reported for M12325 (16).60 The MICs against several strains of influenza virus were comparable to the activity of amantadine, but 16 was less cytotoxic and had a higher $\mathrm{LD}_{50}$. Oral doses of 16 were reported to be effective in reducing influenza induced mortality in mice. 60

Arildone (WIN 38020) - Arildone (17) is a B-diketone which has broadspectrum activity against several important DNA

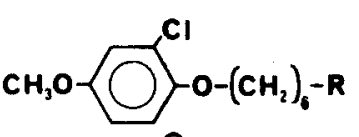

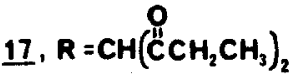

18, $R=$<smiles>Cc1cc(C)on1</smiles>
and RNA viral pathogens. 1,2 An isoxazole analog, WIN 49321 (18), has recently been reported to have antipicornavirus activity. 61 The isoxazole 18 inhibited plaque formation by 24 of 27 human rhinovirus serotypes, poliovirus and Echovirus by $50 \%$ at concentrations ranging from 0.03 to $15 \mu \mathrm{M}$. It was orally effective in protecting mice against poliovirus-induced death in a dose-dependent manner. Mechanism studies show that 18 prevents viral replication by inhibiting the virion uncoating process. 61

1-(5-Tetradecyloxy-2-furanyl)ethanone (RMI 15,731) - RMI 15,731 (19) has been reported to be a rhinovirus specific antiviral that directly inactivates virus in<smiles>CCCCCCCCCCCOc1ccc(C(C)=O)o1</smiles>

19 vitro. ${ }^{2}$ In a recent clinical trial, intranasal 19 failed to show significant prophylactic activity in experimental human rhinovirus type 39 infections. 62

\section{DNA VIRUSES}

Significant progress continues to be made in the clinical use and development of agents active against DNA viruses. Acyclovir (9-(2-hydroxyethoxymethyl)guanine) has been the subject of several reviews $53-68$ and of a symposium 69 during the past year. Clinical trial results have been published that attest to the efficacy of oral acyclovir in the treatment of primary 70 and recurrent 71 genital herpes simplex virus (HSV) infections and in the protection of bone marrow transplant patients from herpes infections. ${ }^{2}$ Chronic, oral acyclovir treatment was highly effective in suppressing recurrent herpes simplex genitalis in a group of patients with unusually frequent episodes. 73 Topical acyclovir cream was effective for treatment of recurrent herpes labialis. 74 Considerable progress has been made in evaluating the clinical promise of acyclovir; however, there remains much to be learned concerning the best use of this drug in clinical practice. 75 Some studies on candidate prodrug forms of acyclovir have recently been published. Several esters of acyclovir were reported to have improved 
water solubility.76 A diaminopurine analog A134U (2,6-diamino-9-(2hydroxyethoxymethyl)purine), which is metabolically deaminated to acyclovir by adenosine deaminase, 77 has been reported to be better absorbed from the gut, resulting in higher plasma levels of acyclovir. 78 Several new reports have further documented the potent antiherpetic activity of 9-(2-hydroxy-1-(hydroxymethyl)ethoxymethyl)guanine. This compound has been reported to be highly effective in reducing the severity of both primary and recurrent lesions of HSV-2 in animal models.79,80 It also appears to hold substantial promise in the treatment of human cytomegalovirus (HCMV) based on its specific anti-HCMV activity in vitro. 80,81 In an animal model, 9-(2-hydroxy-1-(hydroxymethyl)ethoxymethyl)guanine was shown to be a potent, orally active, chemotherapeutic agent against Equid herpesvirus. 82 FIAC (2'-fluoro-5-iodo$1-\beta-D$-arabinofuranosylcytosine) has been reported to stabilize cutaneous lesions in immunosuppressed patients suffering from acute herpesvirus infection. 84 A minor metabolite of FIAC, 2'-fluoro-5-methy1-1-B-Darabinofuranosyluracil (FMAU), is also antiherpetic, but, in addition, it has i.p. and p.o. activity against murine leukemias resistant to 1- $\beta-\underline{D}-$ arabinofuranosylcytosine. Pharmacokinetic studies on FIAC and FMAU have been published, 85 and the synthes is and in yitro anti-HSV activities of a series of analogs have been reported. 86 A review of the antiviral activity of BVDU ((E)-5-(2-bromovinyl)-2'-deoxyuridine) and other 5-substituted pyrimidine nucleoside analogs has been published. 87 Several 2',3'-diester and 5'-monoester prodrug forms of ara-A ( $9-(1-B-D-a r a b i n o f u r a n o s y l)$ adenine) have been evaluated with favorable results in HSV-2 induced genital infections in female guinea pigs. ${ }^{8}$ The $5^{\prime}$-monophosphate of ara-A was found to be as effective as ara-A in the treatment of immunosuppressed patients suffering from varicella-zoster. 89 A carbocyclic analog of ara-A, cyclaradine, and its 5'-methoxyacetate ester have been reported to have activity in an HSV-1 encephalitis animal model that was comparable to the activity demonstrated by ara-A.90 These two compounds may possess some clinical advantage over ara-A due to their low systemic toxicity. The antiviral effects of phosphonoformic acid (PFA, foscarnet sodium), which is presently in Phase III clinical trials in Europe, 83 have been discussed in a recent review. 91 The synthesis and structural requirements for antiherpes activity of a series of PFA esters have also been reported. 92

\section{APPROACHES TO THE DESIGN OE ANTIVIRAL AGENTS}

Significant strides have been made in the development of clinically useful antiviral agents, especially against the DNA viruses of the herpes family. Most of these agents are directed against viral nucleic acid synthesis and require activation by a virus-induced thymidine kinase. Researchers are beginning to focus on other strategies which may produce broader spectrum antiviral agents with different mechanisms of action. Inhibition of polyamine biosynthes is may serve as a suitable target for antiviral drug design. The polyamine antimetabolite methylglyoxal bis(guanylhydrazone) and $\alpha$-difluoromethylornithine, an inhibitor of polyamine biosynthesis, have recently been reported to inhibit replication of human CMV in vitro. 93 Another target is the inhibition of essential methylation reactions. For some viruses, efficient replication is dependent on viral mRNA that has been methylated at its 5'-terminal guanosine residue. Ribavirin $5^{\prime}-t r i p h o s p h a t e$ has been reported to be an effective inhibitor of this capping reaction which is catalyzed by a mRNA(guanine-7-)methyltransferase. 94 Another permutation of this theme is preservation of cellular S-adenosylhomocysteine (SAH) by inhibition of SAH hydrolase. SAH is an endogenous inhibitor of transmethylation 
reactions in which S-adenosylmethionine is the methyl donor. 95 The 2-5A system is one of the mechanisms by which interferon exerts its antiviral effect.96,97 There has been substantial interest in exploiting this system as an approach to antiviral drug development. These efforts have primarily been aimed at the synthesis of 2-5A core analogs that are permeable to cells and stable to degradative enzymes. During the process of infection some viruses change the permeability of infected cells. This allows cellular penetration by compounds that are normally excluded. The selective antiviral activity of hygromycin B supports the suggestion that screening for agents which are selectively permeable to virus infected cells could result in broad-spectrum antiviral agents. $98 \mathrm{~A}$ review of the concept of selective delivery of antiviral agents by conjugation with protein carriers has been published.99 These experiments suggest that the chemotherapeutic index of ara-A for the treatment of chronic hepatitis $B$ could be improved by coupling the agent to lactosaminated albumin. A number of lipophilic amines of diverse structure have in vitro antiviral activity against enveloped viruses including Semliki Forest virus, Sendai virus, vesicular stomatitis virus, and influenza $A$ and $B$ viruses. $100-103$ This activity appears to be mediated by an obligatory lysosomal step in the uncoating of enveloped viruses. Amines such as chloroquine may prevent uncoating by increasing the lysosomal $\mathrm{pH}$ above a value required for release of the virus nucleocapsid into the cytoplasm. A better understanding of this process could lead to the development of broad-spectrum antiviral agents.

\section{References}

1. J.L. Kelley and L. Beauchamp, Annu. Rep. Med. Chem., 18, 139 (1983),

2. J.C. Drach and R.W. Sidwell, Annu. Rep. Med. Chem., 16, 149 (1981).

3. R.F. Schinazi and W.H. Prusoff, Pediatr. Clin. North Am., 3077 (1983).

4. P.E. Hermans and F.R. Cockerill, III, Mayo Clin. Proc., 58, 217 (1983).

5. R.G. Douglas, Jr., Medical Clin. North Am., 67, 1163 (1983).

6. A.G. Bukrinskaya, Advances in Virus Research, 27, 141 (1982).

7. F.J. Tyeryar, J. Infect. Dis., 148, 588 (1983).

8. L.J. Anderson, P.A. Patrlarca, J.C. Hierholzer and G.R. Noble, Medical Clin. North Am., 67, 1009 (1983).

9. E.H. Lennette, Buil. W.H.O., 59, 305 (1981).

10. G.J. Galasso, Antiviral Res., 1, 73 (1981).

11. Y.J. Bryson, Pediatr. Infect. Dis., 1, 44 (1982).

12. D.M. Zlydnikov, O.I. Kubar, T.P. Kovaleva and L.E. Kamforin, Rev. of Infect. Dis., 3. $408(1981)$.

13. R. Dolin, R.C. Reichman, H.P. Madore, R. Maynard, P.N. Linton and J. Webber-Jones, N. Engl. J. Med., 307, 580 (1982).

14. L.P. Van Voris, R.F. Betts, F.G. Hayden, W.A. Christmas and R.G. Douglas, J. Am. Med. Assoc., 245, 1128 (1981).

15. J.M. Quarles, R.B. Courch, J.R. Cate and C.B. Coswick, Antiviral Res., 1, 149 (1981).

16. F.G. Hayden, H.E. Hoffman and D.A. Spyker, Antimicrob. Agents Chemother., 23, 458 (1983).

17. V.M. Millet, M. Dreisbach and Y.J. Bryson, Antimicrob. Agents Chemother., 21, 1 (1982).

18. J.A. Flaherty and S.N. Bellur, J. Clin. Psychiatry, 42, 344 (1981).

19. V.W. Horadam, J.G. Sharp, J.D. Smilack, B.H. McAnalley, J.C. Garriott, M.K. Stephens, R.C. Prati and D.C. Brater, Ann. Intern. Med., 24,454 (1981).

20. M.J. Wu, T.S. Ing, L.S. Soung, J.T. Daugirdas, J.E. Hano and V.C. Gandhi, Clin. Nephrol., 17, 19 (1982).

21. A.G. Bukrinskaya, N.K. Vorkunova, G.V. Kornilayeva, R.A. Narmanbetova and G.K. Vorkunova, J. Gen. Virol., 60, 49 (1982).

22. A.G. Bukrinskaya, N.K. Vorkunova and N.L. Pushkarskaya, J. Gen. Virol., 60, 61 (1982).

23. W.C. Koff, J.L. Elm, Jr. and S.B. Halstead, Am. J. Trop. Med. Hyg., $30,184(1981)$.

24. D.A. Fisher, Cutis, 29, 467 (1982).

25. A.W. Galbraith, Brit. J. Clinical Practice, September, 304 (1983).

26. T.W. Chang and R.C. Heel, Drugs, 22, 111 (1981). 
27. V. Knight, H.W. McClung, S.Z. Wilson, B.K. Waters, J.M. Quarles, R.W. Cameron, S.E. Greggs, J.M. Zerwas and R.B. Couch, Lancet, 2, 945 (1981).

28. H.W. MeClung, V. Knight, B.E. Gilbert, S.2. Wilson, J.M. Quarles and G.W. Divine, J. Am. Med. Assoc., 249, 2671 (1983).

29. J.F. Hruska, P.E. Morrow, S.C. Suffin and R.G. Douglas, Jr., Antimicrob. Agents Chemother., 21, 125 (1982).

30. C.B. Hall, E.E. Walsh, J.F. Hruska, R.F. Betts and W.J. Hall, J. Am. Med. Assoc., 249, 2666 (1983).

31. C.B. Hall, J.T. McBride, E.E. Walsh, D.M. Bell, C.L. Gala, S. Hildreth, L.G. Ten Eyck and W.J. Wall, N. Engl. J. Med., 308, 1443 (1983).

32. D.F Smee, R.W. Sidwell, S.M. Clark, B.B. Barnett and R.S. Spendlove, Antimicrob. Agents Chemother., 20, 533 (1981).

33. W.C. Koff, R.D. Pratt, J.L. Elm, Jr., C.N. Venkateshan and S.B. Halstead, Antimicrob. Agents Chemother., 24, 134 (1983).

34. W.C. Koff, J.L. Elm and S.B. Halstead, Antiviral Res., 2, 69 (1982).

35. P.C. Srivastava and R.K. Robins, J. Med. Chem., 26, 445 (1983).

36. J.J. Kirsi, J.A. North, P.A. McKernan, B.K. Murray, P.G. Canonico, J.W. Huggins, P.C. Srivastava and R.K. Robins, Antimicrob. Agents Chemother., 24, 353 (1983).

37. E. De Clercq and J.A. Montgomery, Antiviral Res., 3, 17 (1983).

38. R.J. Phillpotts, R.W. Jones, D.C. DeLong, S.E. Reed, J. Wallace and D.A.J. Tyrrel, Lancet, 1, 1342 (1981).

39. R.J. Phillpotts, J. Wallace, D.A.J. Tyrrell and V.B. Tagart, Antimicrob. Agents Chemother., 23, 679 (1983).

40. F.G. Hayden and J.M. Gwaltney, Jr., Antimicrob. Agents Chemother., 21, 892 (1982).

41. R.A. Levandowski, C.T. Pachucki, M. Rubenis and G.G. Jackson, Antimicrob. Agents Chemother., 22, 1004 (1982).

42. E.C. Herrmann, Jr., J.A. Herrmann and D.C. DeLong, Antiviral Res., 1, 301 (1981).

43. C.J. Paget, D.C. DeLong, J. Nelson, and J.H. Wikel, Abstracts, 185th American Chemical Society National Meeting, Seattle, Washington, March 20-25, 1983; No. CARB 31.

44. C. Paget, J. Wikel, T. Morwick, T. Suarez, D. DeLong, J. Nelson, J. Quay and R. Bopp, Abstracts, North American Medicinal Chemistry Symposium, University of Toronto, Toronto, Canada, June 20-24, 1982; Poster 94.

45. H.J. Eggers, Handb. Exp. Pharmacol., 61, 377 (1982).

46. E.C. Herrmann, Jr., J.A. Herrmann and D.C. DeLong, Antiviral Res., 2, 339 (1982).

47. E.J. Dubovi, J.D. Geratz, S.R. Shaver and R.R. Tidwell, Antimicrob. Agents Chemother., 19,649 (1981).

48. R.R. Tidwell, J.D. Geratz and E.J. Dubovi, J. Med. Chem., 26, 294 (1983)

49. D.J. Bauer, J.W.T. Selway, J.F. Batchelor, M. Tisdale, I.C. Caldwell and D.A.B. Young, Nature, 292,369 (1981).

50. M. Tisdale and J.W.T. Selway, J. Gen. Virol. 64, 795 (1983).

51. R.J. Phillpotts, J. Wallace, D.A.J. Tyrrell, D.S. Freestone and W.M. Shepherd, Arch. Virol., 75, 115 (1983).

52. Drugs of the Euture, I 542 (1982).

53. H. Ishitsuka, C. Onsawa, T. Ohiwa, I. Umeda and Y. Suhara, Antimicrob. Agents Chemother., 22, 611 (1982).

54. J. Güttner, A. Veckenstedt, H. Heinecke and R. Pusztai, Acta Virol., 26, 148 (1982).

55. A. Veckenstedt and R. Pusztai, Antiviral Res., 1, 249 (1981).

56. H. Ishitsuka, Y.T. Ninomiya, C. Ohsawa, M. Fujiu and Y. Suhara, Antimicrob. Agents Chemother., 22, 617 (1982).

57. Scrip: World Pharmaceutical News, No. 689, p. 13 (1982).

58. R.D. Powers, J.M. Gwaltney, Jr. and F.G. Hayden, Antimicrob. Agents Chemother., 22, $639(1982)$.

59. H.L. Torney, J.K. Dulworth and D.L. Steward, Antimicrob. Agents Chemother., 22, 635 (1982).

60. H. Ohnishi, K. Yamaguchi, S. Shimada, S. Himuro and Y. Suzuki, Antimicrob. Agents Chemother., 22, 250 (1982).

61. M.A. McKinlay, C.J. Brisson, J.V. Miralles and G.D. Diana in "Program and Abstracts, 23rd ICAAC", American Society of Microbiology, Las Vegas, Nevada, 1983, Abstract 160

62. J.M. Gwaltney, Jr. and E.G. Hayden in "Program and Abstracts, 23rd ICAAC", American Society for Microbiology, Las Vegas, Nevada, 1983, Abstract 931.

63. D. Barry and R. Blum, in "Recent Advances in Clinical Pharmacology", Vol. 3, D.G. Shand and P. Turner, Ed., Churchill Livingstone Inc., New York, 1983, p. 57.

64. B. Bean, Postgrad. Med., 73(3), 297 (1983).

65. D.M. Richards, A.A. Carmine, R.N. Brogden, R.C. Heel, T.M. Speight and G.S. Avery, Drugs, 26, 378 (1983).

66. O.L. Laskin, Clin. Pharmacokinet., 8,187 (1983).

67. C.C. Rudd, Drug. Ther. Hosp., $8(9), 41$ (1983) 
68. H.J. Rogers and A.S.E. Fowle, J. Clin. Hosp. Pharm., 8, 89 (1983),

69. J. Antimicrob. Chemother., 12 Suppl. B, (1983).

70. Y.J. Bryson, M. Dillon, M. Lovett, G. Acuna, S. Taylor, J.D. Cherry, B.L. Johnson, E. Wiesmeier, T. Creagh-Kirk and R. Keeney, N. Engl. J. Med., 308, 916 (1983).

71. R.C. Reichman, G.J. Badger, G. J. Mertz, L. Corey, D. Richman, M. Oxman, J. Connor, Y. Bryson, D. Tyrrell and J. Partnoy, Clin. Res., 31, 373 A (1983).

72. E. Gluckman, J. Lotsberg, A. Devergie, X.M. Zhao, R. Melo, M. Gomez-Morales, T. Nebout, M.C. Mazeron and Y. Perol, Lancet, 2, 706 (1983).

73. S. Straus, M. Seidlin, H. Takiff, S. Bachrach, J. DiGiovanna, K. Western, T. Creagh-Kirk, L. Lininger and D. Alling, Clin. Res., 31, 543A (1983).

74. A.P. Fiddian, J.M. Yeo, R. Stubbings and D. Dean, Br. Med. J., 286, 1699 (1983).

75. D. Brigden, R.E. Keeney and D.H. King, J. Antimicrob. Chemother, 12, Suppl. B, 195 (1983).

76. L. Colla, E. De Clercq, R. Busson and H. Vanderhaeghe, J. Med. Chem., 26, 602 (1983).

77. T. Spector, T.E. Jones and L.M. Beacham, III, Biochem. Pharmac., 32, 2505 (1983).

78. H.C. Krasny, S.H.T. Liao and S.S. Good, Clin. Pharmac. Ther., 33, 256 (1983).

79. E.B. Fraser-Smith, D.F. Smee and T.R. Matthews, Antimicrob. Agents Chemother., 24 , 883 (1983).

80. A.K. Field, M.E. Davies, C. DeWitt, H.C. Perry, R. Liou, J. Germershausen, J.D. Karkas, W.T. Ashton, D.B.R. Johnston and R.L. Tolman, Proc. Natl. Acad. Sci. USA, 80, $4139(1983)$.

81. E. C. Mar, Y. -C. Cheng and E.-S. Huang, Antimicrob. Agents Chemother., 24,518 (1983).

82. E.A. Rollinson and G. White, Antimicrob. Agents Chemother., 24, 221 (1983).

83. Scrip: World Pharmaceutical News, No. 834, p. 14 (1983).

84. C.W. Young, R. Schneider, B. Leyland-Jones, D. Armstrong, C.T.C. Tan, C. Lopez, K.A. Watanabe, J.J. Fox and F.S. Philips, Cancer Res., 43, 5006 (1983).

85. F.S. Philips, A. Feinberg, T.-C. Chou, P.M. Vidal, T.-L. Su, K.A. Watanabe and J.J. Fox, Cancer Res., 43, 3619 (1983).

86. K.A. Watanabe, T.-L. Su, R.S. Klein, C.K. Chu, A. Matsuda, M.W. Chun, C. Lopez and J.J. Fox, J. Med. Chem., 26, 152 (1983).

87. E. De Clercq, Pure and Appl. Chem., 55, 623 (1983).

88. W.M. Shannon, G. Arnett, D.C. Baker, S.D. Kumar and W.I. Higuchi, Antimicrob. Agents Chemother., 24, 706 (1983).

89. J.L. Vilde, F. Bricaire, A. Huchon and F. Brun-Vezinet, J. Med. Virology, 12, 149 (1983).

90. W.M. Shannon, L. Westbrook, G. Arnett, S. Daluge, H. Lee and R, Vince, Antimicrob. Agents Chemother., 24, 538 (1983)

91. B. Obers, Pharmac. Ther., 19, 387 (1983).

92. J.O. Norén, E. Helgstrand, N.G. Johansson, A. Misiorny and G. Stening, J. Med. Chem., 26, 264 (1983).

93. A.S. Tyms and J.D. Williams, Nature, 297, 690 (1982).

94. B.B. Goswami, O.K. Sharma and E. Borek, Recent Results in Cancer Research, 84, 275 (1983).

95. E. De Clercq, Nucl. Acid Res., Series No. 11, 203 (1982)

96. P.F. Torrence, K. Lesiak, J. Imai, M.I. Johnston and H. Sawai, in "Nucleosides, Nucleotides and Their Biological Applications", J.L. Rideout, D.W. Henry and L.M. Beacham, III, Ed., Academic Press, New York, 1983, p. 67.

97. R.J. Suhadolnik, Y. Devash, P. Doetsch, E.E. Henderson, J.M. Wu, W. Pfleiderer and R. Charubala, in "Nucleosides, Nucleotides and Their Biological Applications", J.L. Rideout, D.W. Henry and L.M. Beacham, III, Ed., Academic Press, New York, 1983, p. 147.

98. J.-C. Lacal and L. Carrasco, Antimicrob. Agents Chemother., 24, 273 (1983).

99. L. Fiume, C. Busi and A. Mattioli, EEBS Lett., 153, 6 (1983).

100. D.K. Miller and J. Lenard, Proc. Natl. Acad. Sci. USA, 78, 3605 (1981).

101. J. Lenard and D.K. Miller, Cell, 28, 5 (1982).

102. A. Helenius, M. Marsh and J. White, J. Gen. Virol., 58, 47 (1982).

103. M. Shibata, H. Aoki, T. Tsurumi, Y. Sugiura, Y. Nishiyama, S. Suzuki and K. Maeno, J. Gen. Virol., 64, 1149 (1983). 